\title{
PENGEMBANGAN BAHAN PEMBELAJARAN PENGENALAN MATEMATIKA DASAR BERBASIS KOMPUTER BAGI ANAK USIA DINI
}

\author{
Hendrayatna Prawiranegara, S.Kom, M.Pd \\ e-mail: javidr2008@gmail.com.
}

Direktorat Jenderal Guru dan Tenaga Kependidikan, Kementerian Pendidikan dan Kebudayaan Gedung D Kemendikbud Lantai 11 JI. Jenderal Sudirman Senayan Jakarta, 10270

\begin{abstract}
Abstrak: Penelitian ini bertujuan mengembangkan bahan pembelajaran pengenalan metematika dasar berbasis komputer pada Taman Kanak-kanak di Sekolah Alam Bintaro, Jakarta-Selatan tahun ajaran 2018-2019. Bahan pembelajaran pengenalan matematika dasar yang dikembangkan bagi anak usia dini ini meliputi 1. Analysis, 2. Design. 3. Development, 4. Evaluation, Test and revise, 5). Implementation. hasil produk pembelajaran diimplementasikan melalui; 1) Pengenalan Pembelajaran simulasi matematika dasar melalui pemanfaatan web based learning, 2) tutorial dan simulasi matematika bagi guru dan siswa. Agar dapat divalidasi secara akademik dan ilmiah, prototype pengembanggan pembelajaran divalidasi melalui tiga tahap pengujian produk secara teknik sebagai sebuah bahan pembelajaran, yaitu; 1) pengujian produk, teknik sebagai sebuah perangkat lunak, 2) pengujian produk sebagai sebuah bahan pembelajaran, dan 3) uji coba lapangan terhadap guru dan anak-anak di Taman Kanak-kanak di Sekolah Alam Bintaro, Jakarta-Selatan. Hasil penelitian menunjukkan bahwa pengembangan bahan pembelajaran pengenalan metematika dasar berbasis komputer pada Taman Kanak-kanak di Sekolah Alam Bintaro efektif untuk meningkatkan perkembangan kognitif anak terutama matematika dasar, serta motivasi belajar, dan belajar mengenal angka melalui pembelajaran matematika berbasis komputer.
\end{abstract}

Kata-kata kunci: Pengembangan Pembelajaran, Matematika Dasar, Metode Simulasi, Komputer

\section{THE DEVELOPMENT OF COMPUTER-BASED BASIC MATH LEARNING MATERIAL FOR EARLY CHILDHOOD}

\begin{abstract}
The purpose of this study is to develop basic math learning based on computer for children in one kindergarten at South Jakarta. The introduction of basic math learning materials for early childhood include 1. Analysis, 2. Design. 3. Development, 4. Test, evaluation and revision, 5). Implementation. The instructional product prototype are implemented through; 1) Introduction to basic math simulations through the use of web based learning, 2) math tutorials and simulations for teachers and students. The learning support prototype is validated through three stages of product testing as a learning material, namely; 1) product testing as a computer software 2) product testing as a learning material, and 3) field trials for teachers and children in one kindergarten at South Jakarta. The results showed that the development of learning materials for the introduction of basic computer-based mathematics in kindergartens at Bintaro natural school was effective in improving children's cognitive development, especially basic mathematics, as well as learning motivation, and understanding numbers through computer-based mathematics learning.
\end{abstract}

Keywords: Learning Development, Basic Mathematics, Simulation Methods, Computers. 


\section{PENDAHULUAN}

Penggunaan dan pemanfaatan media untuk pembelajaran dalam penerapan pendidikan anak usia dini mempunyai kedudukan yang sangat penting dalam mencapai tujuan pembelajaran. Penggunaan dan pemanfaatan media sebagai bahan pembelajaran sangat dianjurkan untuk mempertinggi kualitas pembelajaran diantaranya melalui komunikasi yaitu dengan adanya penyampaian pesan dari sumber informasi berupa pesan melalui media pembelajaran.

Belajar merupakan suatu proses yang sangat kompleks pada diri seseorang yang bersifat individual di setiap masa kehidupannya. Proses belajar terjadi dikarenakan adanya interaksi antara seseorang dengan lingkungannya. Oleh karena itu belajar dapat terjadi kapan dan di mana saja. Salah satu tanda seseorang itu telah melakukan belajar adalah terdapat adanya perubahan tingkah laku pada individu yang dapat dilihat melalui aspek pengetahuan (cognitive), psikomotor (psychomotor), dan sikap (affective).

Apabila proses belajar tersebut diselenggarakan secara formal di sekolah tujuannya antara lain adalah untuk mengarahkan perubahan pada diri peserta didik secara terencana, baik dalam aspek pengetahuan, keterampilan maupun sikap yang disesuaikan dengan kebutuhan, tuntutan dan kurikulum. Semakin kompleks tuntunan sebuah kurikulum, bertambah kompleks pula tuntutan sarana dan prasarana yang dibutuhkan. Interaksi yang terjadi selama proses belajarpun semakin banyak ragamnya dan semakin tinggi intensitasnya. Interaksi tidak lagi terbatas hanya guru dan peserta didik, namun peserta didik dengan peserta didik pula, tetapi juga antara peserta didik dengan pesan pada pembelajaran secara langsung. Baik itu melalui media pembelajaran maupun dengan lingkungan sebagai sumber belajar.

Pemanfaatan, penerapan dan Penggunaan Teknologi pembelajaran di sekolah merupakan sebuah inovasi dalam aktivitas pembelajaran melalui pendekatan teknologi baru. Pemanfaatan, penggunaan dan penerapan teknologi informasi dan komunikasi (TIK) dalam dunia pendidikan telah mengubah pola dan interaksi altivitas pembelajaran. Berbagai strategi, metode, media dan model pembelajaran yang berbasis teknologi dan informasi (TIK), telah dikembangkan oleh banyak ahli pendidikan yang bekerjasama dengan ahli TIK. Smaldino, Lowther dan Russel (2012:235), mengemukakan tentang belajar online (juga dikenal dengan belajar electronic learning atau e-learning merupakan nilai dari pengajaran yang disampaikan secara elektronik menggunakan media berbasis komputer, materialnya sering kali di akses melalui sebuah jaringan, termasuk situs web, internet dan CD dan DVD. E-learning tidak hanya mengakses informasi, tetapi juga membantu para peserta didik dengan hasil-hasil yang spesifik, selain menyampaikan pembelajaran, e-learning dapat memantau kinerja peserta didik dan melaporkan kemajuan peserta didik.

Spector (2012:27) mengatakan, belajar didefinisikan sebagai perubahan dalam satu kemampuan, sikap, keyakinan, perubahan dan keterampilan. Schunk (2012: 5) mendefinisikan pembelajaran merupakan perubahan yang bertahan lama dalam perilaku, atau dalam kapasitas berperilaku dengan cara tertentu, yang dihasilkan dari praktik atau bentuk-bentuk pengalaman lainnya. Proses pembelajaran mempunyai tujuan yaitu agar siswa dapat mencapai kompetensi seperti yang diharapkan. Untuk mencapai tujuan tersebut proses pembelajaran perlu dirancang secara sistematik dan holistik.

Pendapat ahli di atas mengenai belajar, merupakan perubahan seseorang dalam perubahan kemampuan, sikap, keyakinan dan keterampilan juga kapasitasnya dalam berperilaku. Proses pembelajaran didasarkan atas tujuan pembelajaran, maka pembelajaran perlu dirancang agar aktivitas dan proses pembelajaran tercapai sesuai kompetensi peserta didik secara utuh.

Brown dan Green (2016: 6), mengemukakan bahwa "desain pembelajaran merupakan pengembangan sistematis, spesifikasi pembelajaran dengan menggunakan pembelajaran dan teori instruksional untuk menjamin kualitas dalam penerapan pembelajaran. Ini adalah seluruh proses analisis kebutuhan dan tujuan dan pengembangan sistem pengiriman pembelajaran untuk memenuhi kebutuhan tersebut. Ini termasuk pengembangan bahan dan kegiatan pembelajaran; ujicoba dan evaluasi dari semua kegiatan instruksi dan pelajar/peserta didik." Sedangkan Smith dan Ragan dalam Richey (2011:2), mendefinisikan pengembangan instruksional merupakan "The systematic and reflective process of translating principles of learning and instruction into plants for instructional material, activities, information resources, and evaluation". Dari kedua pendapat di atas, dapat disimpulkan bahwa pengembangan instruksional adalah merupakan proses sistematis penerjemahan prinsip-prinsip pembelajaran dan pengajaran ke dalam rencana pembelajaran untuk diaplikasikan kedalam materi pembelajaran, kegiatan, sumber informasi, dan evaluasi pembelajaran. 
Richey, Fields, dan Foxon yang dikutip oleh Rothwell dan Kazanas $(2004 ; 245)$, mengatakan bahwa, standar kompetensi untuk desain instruksional adalah untuk memilih atau memodifikasi bahan pembelajaran yang ada. Hal ini dianggap sebagai sebuah kompetensi penting. Oleh sebab itu, Laporan kinerja yang terkait dengan kompetensi ini menunjukkan bahwa, desainer instruksional harus mampu;

a. Mengidentifikasi materi pembelajaran yang ada untuk digunakan kembali atau modifikasi sesuai dengan spesifikasi instruksional.

b. Pilih bahan untuk mendukung analisis isi, teknologi yang diusulkan, metode penyampaian, dan strategi pengajaran.

c. Gunakan analisis biaya-manfaat untuk memutuskan apakah akan memodifikasi, pembelian, atau mengembangkan bahan pembelajaran.

d. Bekerja dengan ahli subjek-materi untuk memvalidasi pilihan atau modifikasi material.

Desain model pembelajaran merupakan gambaran proses rancangan sistematis tentang pengembangan pembelajaran baik mengenai proses maupun bahan pembelajaran yang sesuai dengan kebutuhan dalam upaya pencapain tujuan. Joyce, well dan Calhoun (2009: 6), mengatakan bahwa model instruksional adalah deskripsi dari lingkungan belajar, termasuk perilaku kita sebagai tenaga pendidik saat model digunakan. Model memiliki banyak kegunaan mulai dari perencanaan pelajaran kurikulum, merancang bahan ajar, termasuk di dalamnya merancang program multimedia untuk pembelajaran.

Pendapat ahli di atas mengenai model pembelajaran dapat disimpulkan bahwa model pembelajaran merupakan serangkaian penerapan pembelajaran berupa penerapan strategi pembelajaran, metode pembelajaran, media pembelajaran dan evaluasi pembelajaran, semua itu merupakan perencanaan dalam pencapaian tujuan pembelajaran atas kompetensi yang dibutuhkan peserta didik.

Model pembelajaran memberikan cukup banyak fleksibilitas untuk memungkinkan seorang guru mengembangkan kreatifitasnya sendiri, seperti insinyur menggunakan daya kreativitasnya dalam kegiatan membangun sebuah bangunan. Sebagaimana cetak biru, model mengajar adalah rancangan untuk mengajar dimana guru menggunakan segala keahlian dan pengetahuan yang mereka miliki (2012: 8). Interaksi komponen-komponen tersebut mengacu pada tujuan atau kompetensi pemilihan substansi, strategi pembelajaran, metode, media, dan ragam penilaian hasil belajar didasarkan pada tujuan atau kompetensi yang dikuasai siswa.

Pendapat di atas tentang model pembelajaran dapat disimpulkan model pembelajaran adalah sesuatu yang menggambarkan adanya pola berpikir. Dan umumnya bahwa model pembelajaran menggambarkan seluruh konsep yang berkaitan, serta model pembelajaran dipandang sebagai upaya untuk mengkonkretkan sebuah teori sekaligus merupakan analogi dan representasi dari variabel-variabel yang terdapat dalam teori tersebut. Berdasarkan teori-teori tentang belajar, desain pembelajaran dan model pembelajaran yang sudah dijelaskan sebelumnya maka sangat dimungkinkan mendesain seperangkat media pembelajaran menggunakan teknologi komputer. Dengan menggunakan komputer materi pelajaran yang masih bersifat abstrak dapat dikonkritkan, sehingga siswa Taman Kanak-kanak dapat memahami meteri pelajaran dengan mudah.

Teknologi dan media berperan memberikan kepada guru sebagai perkakas untuk melibatkan siswa dalam proses pembelajaran. sebagai seorang guru, harus memilih teknologi dan media pembelajaran terbaik bagi anak didiknya. Smaldino, Lowther dan Russell (2012: 11), mengemukakan Teknologi dan media bisa berperan banyak untuk belajar. Jika pengajarannya berpusat pada guru, teknologi dan media digunakan untuk mendukung penyajianpenyajian program pembelajaran. Di sisi lain, apabila pengajaran berpusat pada peserta didik, para peserta didik merupakan pengguna utama teknologi dan media. Para peserta diidk dapat memanfaatkan teknologi dan media dalam serangkaian cara untuk dapat meningkatkan hasil program pembelajaran. Media seringkali dirancang dan dikemas oleh pengembang pembelajaran dan diberikan dalam mencapai tujuan untuk meningkatkan hasil belajar, berbagai macam bahan pembelajaran disusun dan panduan evaluasi mandiri disediakan.

Marzano, Pickering dan Pollock yang dikutip Smaldino dkk (2012: 30), mengatakan, Para guru memiiki pengaruh yang signifikan terhadap siswa mereka. Strategi pengajaran yang dipilih oleh para guru mempengaruhi hasil belajar siswa. Oleh karena itu para guru, harus selektif dalam pilihan yang mereka buat. Dasar teori dan penilitian mengenai pengajaran menunjukkan bahwa guru bertindak sebagai pemandu untuk meningkatkan pembelajaran siswa. Cara Memahami bagaimana teknologi cocok dengan pembelajaran, guru harus terlebih dahulu memiliki gambaran yang sangat jelas tentang sifat belajar mengajar. Guru membuat acara belajar mengajar untuk 
mentransfer pengetahuan dan keterampilan kepada siswa mereka. Oleh karena itu, teknologi adalah alat kunci dalam proses penerapan pembelajaran. Duffy dan McDonald (2011:9).

Mengajar adalah hal yang sistematis, terencana, dari urutan, peristiwa yang memfasilitasi komunikasi dan ide, konsep, atau keterampilan untuk pelajar/peserta didik. Tindakan mengajar membutuhkan pemahaman pembelajaran dan pemahaman tentang faktor-faktor individu dan lingkungan yang mempengaruhi pelajar/ peserta didik. Hal itu juga memerlukan pemahaman tentang diri sendiri dan faktor individu serta lingkungan yang mempengaruhi guru. Setiap guru memiliki gaya belajar tersendiri, gaya kognitif, dan kecerdasan yang dominan.

Melakukan perencanaan untuk mengelola proses pembelajaran yang akan berlangsung di dalam kelas merupakan dasar untuk melakukan proses transfer ilmu yang efektif. Sedangkan melakukkan peningkatan teknologi pembalajaran sangat sulit dilakukan tanpa memperhatikan rencana pembelajaran oleh karena itu, mengintegrasikan teknologi ke dalam kurikulum yang akan di terapkan merupakan hal yang tidak mudah tanpa memperhatikan pentingnya perencanaan. Rencana pembelajaran itu sendiri berfungsi sebagai panduan yang diikuti selama pelaksanaan transfer ilmu di kelas, sehingga membangun kepercayaan dengan merancang rencana harian atau mingguan dalam proses belajar biasanya dibutuhkan oleh pengelola sekolah.

Mengelola kelas selama integrasi teknologi adalah kunci menyediakan siswa dengan pengalaman terbaik saat menggunakan teknologi. dalam rangka memberikan pengalaman positif bagi siswa, guru harus nyaman dengan teknologi dan proses yang sedang berlangsung dan harus merencanakan dengan hatihati untuk masalah penting yang dapat mempengaruhi pengalaman, termasuk penggunaan peralatan dan penempatan, dukungan yang tersedia selama pelaksanaan, norma-norma untuk perilaku siswa selama penggunaan teknologi, dan penilaian kinerja siswa selama penggunaan teknologi. di samping itu, banyak penelitian menyimpulkan bahwa siswa harus nyaman dengan alat teknologi yang digunakan (seperti perangkat keras atau perangkat lunak program yang digunakan) sehingga tidak akan membatasi keberhasilan pembelajaran. guru harus menyadari bahwa tingkat kenyamanan yang tidak tercapai tanpa terus digunakan untuk anak-anak serta guru, Bannon dan Pucket (2010:26).

Siswa sebagai peserta didik dapat memberikan wawasan ke dalam desain dari pengalaman belajar.
Mereka dapat memberikan umpan balik dalam desain pembelajaran dan peluang pembelajaran. Menggunakan umpan balik sederhana dari siswa dapat menjelaskan atau menunjukkan dalam beberapa cara lain memberikan harapan dan persepsi dari struktur kelas juga berpeluang. Simonson, Akbright dan Zvacek (2012"158).

Bahan Pembelajaran dapat ditampilkan melalui media cetak maupun elektronik. Perbedaannya terdapat dari media yang dipergunakan yaitu media kertas dan media elektronik dengan menggunakan peralatan komputer. Selain itu pada bahan pembelajaran cetak mempunyai sifat self sufficient yang artinya untuk dapat menggunakannya memerlukan alat lain, mudah dibawa ke mana-mana, dan mudah dibaca secara sekilas. Bahan Pembelajaran untuk pembelajaran berbasis web merupakan salah satu bentuk bahan pembelajaran elektronik. Karena bahan pembelajaran tersebut disiapkan, dijalankan, dan dimanfaatkan dengan media internet dengan memerlukan media komputer sebagai alat dalam membantu menyampaikan berbagai macam materi pembelajaran. Komponen yang terdapat pada materi pembelajaran berbasis web yaitu terdiri dari kurikulum pembelajaran, diskusi yang dilakukan pada waktu sekarang maupun asyncrounous, kuis, latihan, tugas, komponen multimedia (animasi, simulasi, permainan, video), arsip peny dilihat dari cara penyusunan dan tampilannya, bahan pembelajaran elektronik dapat di bagi menjadi bahan pembelajaran elektronik biasa, hypertext, dan hypermedia. Bahan pembelajaran elektronik biasa adalah bahan pembelajaran yang disusun dan ditampilkan secara elektronik, susunan naskah secara berurutan dan tata letaknya tidak berbeda dengan buku cetakan. Bahan pembelajaran dalam bentuk hypertext disusun atas dasar konsepkonsep yang saling berhubungan dan tidak berurutan tetapi dalam satu sistem yang memungkinkan pembaca dapat membaca topik-topik yang bersangkutan sesuai dengan keperluannya. Sedangkan bahan pembelajaran hypermedia disusun dan disajikan seperti hypertext tetapi penyimpanan elektronik/ pengumpulan tugas kerja siswa dan web based tools, (2009:1).

Simonson, Smaldino dan Zvacek (2015:105), mengatakan, "With Computer and internet based technologies, however, have come exciting new opportunities for providing learning experiences to students". Pendapat tersebut dapat diartikan bahwa online learning adalah dengan komputer dan jaringan internet berdasarkan teknologi, bagaimanapun juga, mendatangkan hal baru yang menyenangkan 
dan memberikan peluang untuk menciptakan dan mengembangkan perluasan pengalaman belajar siswa.

Gagne, Briggs, dan Wager (2005: 11), mengatakan bahwa pembelajaran (instructional), berarti sebagai seperangkat peristiwa eksternal yang diatur dan dirancang secara sengaja untuk mendukung proses belajar internal. Mengacu kepada pendapat tersebut, kegiatan pembelajaran perlu mempertimbangkan sejumlah tahapan belajar (events of learning) yang harus dilewati agar bisa mencapai tujuan pembelajaran tertentu. Secara umum mereka membagi pembelajaran atas beberapa tahapan yakni: (1) menarik perhatian siswa melalui rangsangan tertentu; (2) menginformasikan tujuantujuan pembelajaran; (3) mengingatkan kembali materi yang sudah dipelajari; (4) menyajikan materi secara jelas; (5) memberikan panduan belajar; (6) meminta memperlihatkan kinerja; (7) menyediakan umpan balik tentang ketepatan kinerja; (8) menilai kinerja belajar; dan (9) meningkatkan retensi dan transfer.

Hasil penelitian Mairi Manamaa, Eve Kikas, Katlin Paats, and Anu Palu (2011), mengupas tentang korelasi kognitif pengetahuan dan keterampilan matematika, mengenai kurangnya peran sentral kognitif dalam kesulitan pembelajaran matematika. Hal tersebut disimpulkan prestasi hasil belajar matematika yang rendah adalah karena kecerdasan yang rendah. Salah satu alasan yang masuk akal, mengapa prestasi belajar matematika dikaitkan dengan beragam keterampilan kognitif dan hal tersebut tidak membangun unit dimensional, tetapi mencakup keterampilan yang berbeda, seperti menghitung, pemecahan masalah kata, mengetahui dan menggunakan algoritma, serta menerapkan kemampuan ini pada tempat yang baru. Dan, kemampuan matematika yang berbeda mungkin memerlukan kemampuan kognitif yang berbeda pula. Ketika menjelaskan tujuan pendidikan matematika, biasanya ada dua dimensi yang berbeda diciptakan: isi tugas (yaitu topik apa yang diajarkan) dan kemampuan kognitif diperlukan untuk memecahkan tugas-tugas ini. Komponen dimensi kognitif (juga disebut proses kompetensi atau kompetensi umum) pengetahuan matematika dan keterampilan yang didefinisikan berbeda di berbagai negara (Educational Psychology, Victoria University Wellington, 2012: 21-24).

Berdasarkan hasil studi pendahuluan, melalui wawancara guru di Taman Kanak-kanak Sekolah Alam Bintaro, review hasil belajar dan pembelajaran secara umum serta observasi fasilitas sumber belajar di taman Kanak-kanak tersebut menunjukan bahwa pengenalan belajar Matematika dasar yang berlangsung di taman Kanak-kanak Sekolah Alam Bintaro belum memanfaatkan teknologi informasi, oleh karena itu kami peneliti memandang perlu adanya pemanfaatan media pembelajaran alternatif yang mana mereka tidak merasa belajar melainkan sedang bermain agar penerapan pembelajaran dan fasilitas sumber belajar kreatif yang tersedia sebagai penunjang kegiatan belajar bagi perkembangan kognitif anak.

Aktivitas pembelajaran yang berlangsung saat ini pada umumnya kurang menggali dan meningkatkan kegiatan belajar peserta didik ke arah terciptanya tujuan pembelajaran khususnya pengenalan matematika dasar yang menarik. Berdasarkan masalah diatas maka diperlukan pembelajaran alternatif dan bahan ajar yang dapat mendukung proses kegiatan belajar pengenalan matematika dasar melalui Pemanfaatan Teknologi Informasi dan komunikasi khususnya media Komputer yang dikhususkan pada siswa Taman Kanak-kanak Sekolah Alam bintaro. Sedangkan manfaat dari penelitian ini adalah secara praktis, bahan ajar ini dapat dijadikan acuan bagi lembaga Taman Kanak-kanak, guru, maupun masyarakat yang ingin mengembangkan bahan ajar pengenalan matematika dasar yang dikhususkan bagi anak usia Sekolah Dasar. Bahan pembelajaran ini menjadi penentu kebijakan dan bahan pembelajaran alternatif dalam rangka mengembangkan dan mengenalkan bahan pembelajaran matematika dasar yang menggunakan media komputer.

\section{METODE PENELITIAN}

Penelitian dan pengembangan ini bertujuan untuk menghasilkan bahan pembelajaran dengan pendekatan simulasi pengenalan matematika dasar dalam bentuk: 1) pembelajaran simulasi matematika melalui pemanfaatan media komputer, 2) tutorial dan simulasi matematika dasar bagi guru dan anak, sebagai perkembangan aktif kognitif siswa taman kanak-kanak dan memotivasi kreativitas serta kemandirian siswa. Pembelajaran berbasis komputer dengan simulasi pengenalan matematika dasar melalui pemanfaatan media komputer ini dikhususkan untuk tingkat pendidikan Taman kanak-kanak.

Penelitian ini dilaksanakan di Sekolah Alam Bintaro, khususnya pada siswa Taman Kanak-kanak. Penelitian dilaksanakan pada tahun ajaran 2017/2018 Penelitian ini hanya sampai pada uji coba lapangan utama.

Pendekatan penelitian yang digunakan dalam 
mengembangkan bahan pembelajaran pengenalan matematika dasar taman kanak-kanak di Sekolah Alam Bintaro menggunakan media komputer, peneliti dalam pengembangan pembelajarannya menggunakan model pembelajaran J. Moonen yang terdiri dari lima tahapan, yaitu:

1. Analysis

Langkah pertama yang dilakukan pada penelitian ini, adalah menerapkan model desain J. Moonen dengan melakukan dua aspek yaitu studi kelayakan dan penyusunan proposal proyek pada studi kelayakan, dengan mengkaji indikator-indikator dari segi pendidikan organisasi teknis serta dari segi ekonomis, selanjutnya proses pengembangan masuk pada tahap desain.

2. Design

Tahap Desain, pada tahap ini dilakukan spesifikasi produk dari aspek pembelajaran dan fungsionalitasnya. Desain pembelajaran disusun agar dapat merefleksikan tujuantujuan pembelajaran analisis materi strategi dan metode pembelajaran, tingkat interaksi dan prosedur evaluasi, dengan melakukan hal tersebut akan memperoleh suatu rancangan produk pembelajaran yang dapat digunakan dengan baik oleh pengguna. Setelah melalui tahapan desain, kemudian hasil rancangan media pembelajaran yang telah dibuat diaplikasikan pada tahap pengembangan.

3. Development

Pada tahapan ini keiatan teknis mendominasi secara keseluruhan. Kegiatan produksi dimulai dengan mengkaji informasi-informasi dan data yang disusun pada tahapan fungsional. Setelah itu, hasil kajian tersebut di implementasikan dengan menggunakan authoring tools yang telah dipilih, sehingga akan menghasilkan sebuah produk berupa media pembelajaran elektronik.

4. Evaluation

Pada tahapan ini setelah produk selesai, maka media pembelajaran tersebut diujicobakan dan di evaluasi dengan metode evaluasi formatif. Tujuan dari kegiatan ini adalah untuk mendapatkan informasi dan masukan yang dilakukan pengembang untuk memperbaiki prototype produk yang dihasilkan.

5. Implementation

Dalam tahap pelaksanaan bahan pembelajaran pengenalan matematika dasar bagi taman kanak-kanak berbasis komputer, pelaksaananya terbagi pada pada dua tahap. Tahap pertama dalam guru mengajar bahan pembelajaran pengenalan matematika dasar tersebut, guru mempelajari menurutpanduan penerapan bahan pembelajaran tersebut. Tahap kedua adalah, Dalam tatap muka dikelas lab Komputer, guru memberikan materi pembelajaran tersebut menggunakan pendekatan simulasi kepada siswa agar tertarik mempelajari matematika dasar.

Teknik pengumpulan data dilakukan menggunakan instrumen yang berupa angket. Sebelum angket digunakan terlebih dahulu dilakukan pengujian sebagai berikut:

Sebelum angket digunakan dalam pengambilan data, terlebih dahulu dilakukan pengujian validitas konstruk dengan pendapat dari ahli (Expert review) Setelah angket dikonstruksikan tentang aspek-aspek yang akan diukur berlandaskan teori tertentu, maka selanjutnya dikonsultasikan dengan ahli. Para ahli diminta pendapatnya tentang instrument yang telah disusun itu.

Teknik analisis data yang digunakan adalah statistik deskriptif kualitatif. Statistik deskriptif kualitatif digunakan untuk menganalisa data dengan cara mendeskripsikan atau menggambarkan data yang telah terkumpul sebagaimana adanya tanpa bermaksud membuat kesimpulan yang berlaku untuk umum atau generalisasi.

\section{A. Angket}

Data angket yang diperoleh dari hasil validasi ahli materi, ahli desain instruksional, ahli media, uji coba satu-satu, uji kelompok kecil dan uji coba lapangan, kemudian diolah menggunakan modifikasi skala Likert yaitu skala 4.4 = sangat Baik, 3 = Baik, 2= Cukup Baik, 1 = Kurang Baik.

\section{HASIL DAN PEMBAHASAN}

\section{Model Pengembagan Bahan Pembelajaran}

Model Draft 1, bahan pembelajaran pengenalan matematika dasar berbasis computer untuk Taman Kanak-kanak Sekolah Alam Bintaro yaitu; pembelajaran pengenalan dasar matematika yang dikembangkan berupa pengenalan belajar dasar matematika melalui komputer melalui simulasi dan games. Adapun isi materi yang terdapat dalam product awal tersebut 
meliputi materi yang ada pada pokok bahasan matematika yang dijelaskan di bawah ini;

1. Mengenal konsep angka

Anak-anak mengenal angka dengan menghitung benda yang menarik sebagai tampilannya

2. Mengenal konsep pola dan hubungan Pola merupakan susunan benda yang terdiri atas warna, bentuk, jumlah, atau peristiwa. Contoh susunan pola berdasarkan ukuran: besar, kecil, besar, kecil. Susunan pola berdasarkan warna: merah, biru, merah, biru.

Kedua Pokok bahasan di atas menggunakan metode simulasi animasi komputer agar siswa dapat mudah mengerti pokok bahasan dalam pembelajaran matematika yang disajikan. Selanjutnya model Draft 1 ini di-review oleh pakar materi pembelajaran matematika, Pakar Desain pembelajaran dan Pakar Media.

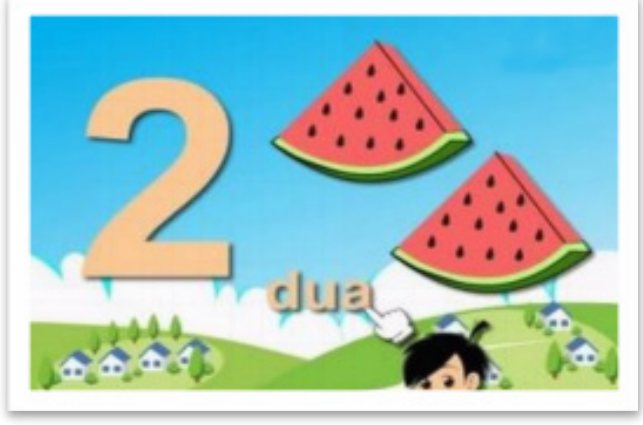

Gambar 1

Model Draft 2, berisikan draft bahan pembelajaran pengenalan matematika dasar bagi anak-anak, yang telah di-review oleh pakar materi pembelajaran Matematika, ahli desain pembelajaran dan pakar media Pembelajaran. Untuk ahli materi pembelajaran Matematika dasar, input yang diberikan pakar menyatakan materi pengenalan matematika dasar untuk anak-anak sudah baik seperti penggambaran angka dengan simulasi benda, namun perlu diperhatikan dan disesuaikan lagi dengan kebutuhan guru yang mengajar di Taman Kanak-kanak Sekolah Alam Bintaro tersebut.

Untuk ahli desain pembelajaran memberikan input, pada desain pembelajaran matematika berbasis web ini yaitu perlu di upgrade pada bagian layout untuk lebih menarik perhatian, mengingat audience adalah anak-anak dan desain agar lebih kreatif terutama pada soal latihan agar lebih menarik dan memotivasi siswa.

Selanjutnya masukan dari ahli media pembelajaran agar produk menggunakan warna yang menarik dan cerah agar anak lebih termotivasi untuk belajar dan layout perlu di perhatikan dan direvisi kembali, agar meningkatkan appealing anak-anak.

\section{Efektivitas Model Melalui Uji Coba 1) Tanggapan guru}

Produk multimedia yang dikembangkan oleh peneliti mengandung materi yang telah disesuaikan dengan ruang lingkup pengenalan Matematika di Taman Kanak-kanak. Anak-anak mencoba pembelajaran multimedia interaktif mengenai pengenalan Angka dilengkapi dengan tombol petunjuk yang menjelaskan fungsi dari tombol-tombol yang ada dalam multimedia, walaupun tanpa bantuan guru peserta didik dapat belajar mandiri menggunakan multimedia pembelajaran interaktif pengenalan Angka tersebut. Penyajian materi pada multimedia pembelajaran interaktif yang dilengkapi dengan gambar dan animasi yang disajikan secara menarik sehingga secara tidak langsung mengajak anak-anak untuk terlibat secara auditif dan visual. Hal itu sesuai dengan yang dinyatakan oleh Mayer (2009: 270) bahwa teks yang disajikan secara bersamaan dengan gambar memungkinkan informasi yang diterima mudah dimengerti oleh peserta didik.

\section{PENUTUP}

\section{Kesimpulan}

Pada bagian ini disimpulkan beberapa hal, dengan berasaskan pada rumusan penelitian dan data yang diperoleh dari hasil evaluasi selama poses pengembangan pembelajaran matematika dasar yang diperuntukkan siswa Taman Kanak sekolah alam Bintaro berbasis komputer sebagai berikut:

1. Penelitian dan pengembangan yang telah dilakukan menghasilkan model fisik berupa prototype bahan pembelajaran pengenalan Matematika dasar anak-anak berbasis komputer terdiri darl konsep pembelajaran pengenalan Matematika dasar, strategi simulasi, dan metode latihan berulang, serta penilaian.

2. Pengembangan paket pembelajaran pengenalan matematika dasar diperuntukkan siswa Taman Kanak-kanak berbasis komputer ini telah melalui beberapa tahapan evaluasi dan perbaikan-perbaikan. Evaluasi formatif yang telah dilakukan seperti one-to-one expert review, Ahli materi pembelejaran matematika, Ahli desain dan Ahli Media pembelajaran. 
Dan juga dari implementasi produk terhadap siswa dari uji efektivitas (field trial). Pada uji efektivitas diperoleh hasil, bahwa dengan adanya produk pembelajaran pengenalan matematika dasar berbasis komputer ini, anak-anak yang menggunakan produk pembelajaran tersebut lebih termotivasi dan antusias serta, giat melakukan latihan Soal-soal pengenalan matematika dasar untuk dipelajari. Ini berarti bahwa pengembangan pembelajaran matematika yang dikembangkan efektif digunakan untuk meningkatkan motivasi belajar, dan belajar mandiri anak agar perkembangan kogniti anak di Taman Kanak-kanak Sekolah Alam Bintaro dapat optimal.

\section{Saran}

Saran-saran yang dapat diberikan terhadap hasil peneliti ini adalah sebagai berikut:

1. Bagi peneliti atau pengembang selanjutnya, disarankan agar terus melakukan peningkatan kualitas baik secara segi media dan desain instruksional. Peningkatan kualitas dengan cara meningkatkan substansi/isi materi pembelajaran untuk menghasilkan prototype pembelajaran yang lebih inovatif dan dibutuhkan.

2. Pengembangan prototype pembelajaran pengenalan matematika dasar yang diperuntukkan bagi Siswa taman Kanak-kanak sekolah alam Bintaro, menggunakan metode simulasi dan latihan berulang dan penilaian yang terdapat dalam bahan pembelajaran dapat dimanfaatkan untuk alternatif bahan pembelajaran mandiri yang meningkatkan motivasi dan kognitif anak.

Di adakannya sosialisasi kepada guruguru taman kanak-kanak dalam memperkenalkan Matematika dasar Khususnya pembelajaran berbasis komputer, yang menggunakan metode simulasi sebagai kerangka kerja bagi guru dalam menerapkan pembelajaran pengenalan matematika dasar.

\section{DAFTAR PUSTAKA}

Abbie H. Brown dan Timothy D. Green. The Essential Of Instructional Design. Connecting Fundamentals Principles With Process and Practice. Third Edition, New York, Routledge 2016.

Bannon, Blanche, W., O., dan Kathleen Pucket. Preparing to Use Technology, Pearson Education Inc: 2010.

Bruce Joyce, Marsha Well, Emily Calhoun, Models of Teaching Eight (Boston, New York: Pearson, 2009),

Gustafson, Kent, L., and Robert Maribe Branch, Survey Of Instructional Development Models, New York: Eric Clearing House on Information and Technology, Syracuse University, 2002.

J. Michael Spector., Foundations of Educational Technology.NewYork: Routledge, Taylor \& Francis Group, 2012.

Kearsley, Greg, Online Education: New Paradigms for Learning and Teaching, h.1, 2009, http:// technologysource.org/article/online education/. (Diakses 2016).

Lever, Judy, Duffy and Jean B. Mc Donald, Teaching and learning with technology, Fourth Plomp, J., Tjeerd, Ely, Donald P., International Encyclopedia Of Educational Technology, New York : Copywright Elsevier Science Ltd, 1996.Edition,
Boston: Pearson Education, Inc, 2011.

Paul Eggen, Don Kauchak, Strategi dan Model Pembelajaran, (Penerjemah Satrio Wahono, Pearson Education, Inc. 5001 Boylston Street, Boston, PT Indeks tahun 2012 Kembangan Utara, Jakarta Barat)

Rita C. Richey, James D. Klien, and Monica W. Tracey, The Instructional Design Knowledge Base, New York: Routledge, 2011.

Schunk. H. Dale. LearningTheories An Educational Perspective, Sixth Edition : Teori-Teori Pembelajaran Perspektif Pendidikan. Yogyakarta; Pustaka Pelajar, 2012.

Simonson, Michael, Sharon, Smaldino, Michael Albright and Suzan Zvacek. Teaching And Learning at a Distance, Fifth Edition, Pearson Education. Inc. 2012.

Smaldino, Lowther, Russel, Instructional Technology And Media For Learning, Teknologi Pembelajaran And Media Untuk Belajar. Seri Terjemahan Arif Rahman Hakim, Edisi Sembilan, Jakarta: kencana Prenada Media Group, 2011.

William J. Rothwell and H.C Kazanas. Mastering The Instructional Design Process, A Systematic Process, third edition, San Fransisco: Printed In The United State of America, 2004. 